\title{
THE MYTHOLOGY OF KAMPUNG NAGA COMMUNITY
}

\author{
Wahyu Iryana \\ (Islamic University of Sunan Gunung Djati, Bandung)
}

\begin{abstract}
In order to gain understanding of the meaning of symbolic variants of the myth in Kampung Naga, an objective analysis is required. Therefore, this paper applied the linguistic model study offered by Levi-Strauss as a new step for the objectivity of myth interpretation. The basic assumption of Levi-Strauss' linguistic model is that myth often display a diverse surface structure, but in fact the diversity is the description of the human deep structure. The selection of this myth was solely based on the life of the Kampung Naga community as part of Sundanese Society. The results indicated that the myth in the religious life of the Kampung Naga community contains a various stories which include the revelation, the reincarnation, and the descent of revelation. These episodes can be constructed into the structure of a Levi-Strauss linguistic model, a binary opposition, namely the mandate giver (active) the mandate recipient (passive). The relationship between the giver and the receiver is vertical (structural) called "structure of three" (regular). From the "structure of three", the "culinary triangle" can be constructed. From the "combined triangle", the Batara Guru will also appear to become a central event that other figures have to go through. Finally, it can be stated that the deep structure construction that still refers to the aspect of Javanese cosmology in General.
\end{abstract}

Keywords: myths, Kampung Naga, Levi-Strauss linguistic model

\section{INTRODUCTION}

To give meaning to the various forms of cultural heritage is an attempt to understand the view of the community in the past in treating ancestral cultural heritage. Tiwi Puspitasari, in the theory of culture, argued that culture is lives in the middle of the community when viewed from the standpoint of semiotics. Whereas the objects of culture and their reference are beyond interpretation or in other words, viewed from perspective of the reader. Among the Sundanese cultural heritage found in the indigenous Sundanese settlement is Kampung Naga, which is located in the village of Neglasari, Selawu, Sub-district, Tasikmalaya District.

As a community who lives in the nature and culture of Sunda, the Sundanese 
have a cosmological view inherited by their ancestors. Culturally, the view of the cosmology is reflected in their mythological world. In a myth there is a prototype that harmoniously unites the contradictory reality and statements. Eliade referred to this model as the coincidentia oppositorum. A myth reveals the structure of divine structure which can overcome and reconcile opposites in more depth than can be expressed by a rational experience. For example, how an empty world is inhabited, how a chaotic situation turns to peace, how the the immortal becomes mortal, how human beings that were originally just a pair turn into various tribes, how other sexless beings become male and female, and so on. The myth not only tells the origin of the world, animals, plants, and human beings, but also the early events that caused them to find their true identity. Through observing a myth in a ritual, one can mimic how to reach the Divine by participating symbolically in a state when humans were created and styled by the Divine.

In general the human behavior can be observed through rituals and myths. The ritual is a stimulus for the inception of myths. Then comes the myths of religion, and it contains the implementation of ritual. When the ritual can be assessed so easily from the results, the myth is no longer necessary. However when the results reflected from the ritual are not clearly visible so if the conviction on this effectiveness must be maintained, then it demands a more complex type of conviction that can only be inferred through myth. Overall function of myth is to reveal, lift and formulate a belief, protect and strengthen the morality, guarantee the efficiency of the ritual, as well as giving practical rules to guide mankind. Myth and religion as a whole play an important role in social life.

Research on the Kampung Naga community will try to explain the problem of cosmology contained in the mythology of the Kampung Naga community who lives in the village of Neglasari, Salawu Sub-district, Tasikmalaya District. This research is expected to indicate that Sundanese Cosmology contained in mythology and spatial arrangement at Kampung Naga is acculturation of the local good teaching derived from prehistoric megalithic tradition, BuddhismHinduism in particular and Islamic teachings. This is because basically mythology is implied from the myths, that rituals, and the traditional arts. The oral stories of myth about the origin of Kampung Naga, as well as the times include space and time. The interview with the kuncen (guardian) of Kampung Naga revealed information that ritual is represented in ceremonies such as Hajat Sasih, Nyepi, harvest, and the ceremony life cyrcle such as gusaran and marriage. With regard to the traditional arts that can still be seen in Kampung Naga are terbanggembrung, angklung, beluk and rengkong or other customs 
like ritual of sasih, wedding ceremony and other traditional ceremonies.

From the historical background, the indigenous peoples of Kampung Naga claim to be descended from Eyang Singaparna, a Muslim who was the last heir to the throne of the Galunggung Kingdom. However, when seen from the way they perform rituals, which are filled with Hindu-Buddhism, and traditional arts that are still thriving in the village, this would be very interesting for further investigation. At least in the form two research contributions, i.e., as a reference to the writer in interpreting symbolic systems in general, and the study of the Sundanese mythology especially the community of Kampung Naga as well for The development of ethnographic studies, especially in order not to get stuck on works of anthropology which are conventional, but to attempt to conduct other studies that determine the path of Indonesian culture.

Kampung Naga interesting and unique to be examined because it is not far from the modern society, even it seems to melt into other communities while at the same time still maintaining and preserving the tradition. This is confirmed also by Suhamihardja (1982: 2) who said that Kampung Naga is a very strong community in preserving the customs of their ancestors. Some ancestral customs of the Kampung Naga community are still held and practiced to date among others, helping each other in construction of homes, the habit in terms of farming that are still relatively modest, and the habit of making traditional calculations, as well as the rituals that accompany them.

The cultural heritage of Indonesia manifested in the various forms of both artifacts and traditions of revealed in indigenous communities should be appropriately appreciated by local researchers so as to live up to the meaning of the culture. However, cultural heritage can be interesting to show as heritage tourism. From the explanation of background above, the writer will focus this research on the mythology of Kampung Naga community.

\section{KAMPUNG NAGA IN THE ACADEMIC DISCOURSE OF JAVANESE CULTURE}

The study of ethnic and cultural rites has lately been examined extensively, and has somewhat dominated the discourse of local wisdom. A lot research and review articles on the concept of world culture might have been examined with different viewpoints. Let us take the research conducted by Tiwi Purwitasari (2010; 119) on "Wacana Desa Budaya dalam Komunitas Budaya" (Cultural Village Discourse in the Community of Culture) as an example that discussed a study of the residential community of culture in West Java.

Trying to connect the indigenous life in Kampung Naga, Tasikmalaya with 
papers and articles that already existed, seems to be something hard, because of the various investigation that the writer did. A general overview about the life of the community of Kampung Naga, Tasikmalaya has been written by a lot of writers, yet to find a cross reference of the mythology of the community of Kampung Naga and its implementation in the social life of the people in a broader meaning is something rarely examined. I also found the works of Toto Sucipto (2001) which is still in the form of a paper entitled "Kampung Adat di Jawa Barat: Menyerap Kearifan Lokal untuk Gagasan Desa Budaya." (Indigenous Village in West Java: Absorbing Local wisdom for the idea of Cultural Village). Here, we can follow from research conducted by Toto where it was revealed that the distinctiveness of the indigenous villages in West Java is the capital for establishing cultural tourism because of its uniqueness that lies in the pattern of natural life and the simplicity of the community still in practice since the time of the ancestors.

As for literature and research results concerning the community of Kampung Naga generally, the discussion is centered mostly about home architecture, ceremonial, and the ecological context of the culture. Studies on the community of Kampung Naga in general view its object using a different perspective, where one study may be seen from its own standpoint. For example, the perspective of space (Adimihardja: 2003) was used as an approach in study the layout of the ground surface settlement, and the architectural perspective in examining residential homes as well as the context of cultural ecology, particularly about the pattern of farming of Kampung Naga community. Research on the Sundanese language in Kampung Naga was conducted by Oyon Sofyan, Syriac, and Elis Sahidin Badru. This research was conducted in 1986 as part of a research project of the Department of Education and Culture. This research was aimed at obtaining an overview of the structure and use of language in Kampung Naga. The Sundanese language is used not only as an everyday language, but also the language used during the performance of rituals. The Sundanese language used during rituals is generally different from the one used in daily life in Kampung Naga.

Other research about the role of the informal leader at Kampung Naga society was conducted by Tjetjep Rosmana and research conducetd Ai Ermala was entitled the Position of Islamic Teachings in the Wedding Tradition of the Kampung Naga Community. This research was conducted in 2003 as a final assignment. It described the wedding traditions in the community of Kampung Naga and how to position these traditions in the teachings of Islam. In the tradition of wedding in Kampung Naga there is syncretism between customary and Islamic elements. This occurs because they do not want to 
eliminate ancestral traditions which are assumed to provide peace of mind. Meanwhile on the other they embrace Islam and the religious element is used as the implementation of compliance to the Creator.

The writer's ideas are in line with the opinion of the symbolic meaning of the myth Dewi Sri proposed by Suwardi in the Javanese society which used the study of Levi-Strauss linguistic model in this regard I rewrote the opinion Badcock (1975: 52-55) where he referred to myth as indeed "something which tells a story". Furthermore, he also stated that myth "does not convey the common sense information, it is not for political purpose. It serves no utilitarian end whatsoever, and conveys no information about the everyday world. Nor is it necessarily morally or politically pedagogic “. This definition indicates that myth is a specific story, meaning that not all stories about contemporariness can be called myths. The myth is part of interesting cultural phenomenon. What we need to note is that, according to Levi-Strauss (Ember and Ember, 1986: 48), socio-cultural phenomena is a representation of the structure beyond that is based on the underlying structure and human. To observe the meaning of myth, Levi-Strauss (Paz, 1995: 9) outlined that the linguistic system established from the relation between phenomena so as to for a binary opposition that can be made the basis of interpretation. In this regard, Levi Strauss (1974: 232) made it clear that in a myth there are relations of units (the structure) which are not isolated, but are a unity of relations combined and used to uncover the meaning behind the myth.

Therefore, in the context of the analysis of myth as well as the study of light reflections which are later combined into a single structure. Therefore, Kerk (1983: 42) argued that myth is associated with community supporters and is a single entity. In fact, Leach (1968: 42) also confirmed that myth and ritual have similar essence. That is, if both are seen from the linguistic point of view, a structural relationship will be found. This sort of thing has been recognized by Levi-Strauss (1980: 14-15) that sought to analyze the myths with the linguistic model. He argued that all versions of the myth are indeed related to the cultural myth of the owner. Levi-Strauss (1963: 208) stated that creation of the myth is indeed irregular, because the owner of the story will tell the story again arbitrarily. However, behind the irregularities, there is actually a regular order that is unconsciously formed by the creator of the myth. The order of the myth is often called the structure. Therefore, in analyzing the myth is in an attempt to find the structure. To find the structure of myth, Levi-Strauss (Bertens, 1996: 186) used the linguistic model as the understanding of sociocultural phenomena.

The basic assumption is that linguistics is considered a system, regardless of 
the historical evolution, and the system contains convincing relationships. Another reason that reinforces Levi-Strauss (Rossi, 1974: 89) to use the linguistic model is because he saw that socio-cultural phenomena as the stem of the signs and symbols that can be transformed into linguistics. Based on the linguistic system, Levi-Strauss (in Ahimsa-Putra, 1995: 5) used the principle of association or analog that myths have a structure similar to linguistics. If Linguistics is used to convey messages, so is the myth. The myth contains a wide variety of new messages, which can be understood if we already know the structure and meaning of the various elements in it. In the linguistic model, there seems to be the opposition system so that in turn it creates the structure of the "two", "three", "four", and so on.

This system can be applied to the analysis of myth. The linguistic model used by Levi-Strauss in the structural analysis of myth, was originally adopted from the theory of structural linguistics of Saussure, Jakobson, and the Troubetzkoy. The adopted model is the concept of sintagmatic and paradigmatic causal agent, langue and parole, synchronous and diachronic (Pettit, 1977: 1). From the model, Levi-Strauss (Ahimsa-Putra, 1994: 45) assumed that myth basically is also similar to the symptoms of linguistics. The use of the linguistic model in structural analysis of Levi-Strauss has been recognized the Greimas (Wagner, 1987: viii) as the tool for analysis which is relevant to myth. In the analysis of myth, Levi-Strauss (Bertens, 1996: 20) needed to show the existence of opposition, because myth is the creation of the human spirit that is totally free. The opposition of the said system according to Creimers and Santo (1997: 151) is called the binary opposition system. This system will be able to reflect the structure of neurobiological factors of both sides of the human brain that functions "digitally". It means that every person and nation has the same binary opposition structures and the only difference that stands out only its realization. Through the linguistic system, Levi-Strauss attempted to combine the diagonal lines to form the structure of the sintagmatic and paradigmatic causal agent that can be used to uncover the meaning of myth in a comprehensive manner.

The cultural value system is the highest and most abstract level of customs. The value of culture is composed of concepts about everything that is important and valued by the members of a society. The value can serve as guidelines for the orientation of the lives of the people concerned. Since a child, a person has been infused by different cultural values that live in the nature of the soul. Therefore, to change the value of a culture that has been owned by other cultural values takes a long time (Koentjaraningrat: 1996).

To facilitate this research in order to find the direction and purpose that 
need to be achieved, there is a need to find the formulation of the problem to be examined in the form of a hypothesis theory which is translated into propositions, i.e., the relationship between the concepts that will be tested. According to Wattie, when problems are found and focused, the search for the concept and the theory of propositions relevant with the problem can begin. The theory in question in this case is a system of ideas (the concept of the proposition) which is interconnected to explain or provide an understanding of the problem. (Wattie, 2006: 40-41).

It is therefore related to the proposed research on Kampung Naga, Tasikmalaya as rural culture: an attempt to interpret the Mythology of Kampung Naga Community. This will refer to the theory of cultural anthropology, but for its analysis, the perspective of the mythology of Kampug Naga Comunity, although it is in the form interpretations as put forward by Geertz (1992), it also will be an integral part in any analysis.

This study refers to the research on cultural anthropology, in particular the cognitive anthropology. Anthropology is the study of the life of humans in a particular region with the aim of reconstructing the cultural history, the human way of life, and the cultural process.

Meanwhile, cognitive anthropology is the scientific study of anthropology that seeks to study and use symbolic systems to deal with problems of cultural anthropology. To reach that goal, the implementation in the field, this research used various phases starting from observation, description, and finally empirical research. The search process was observation and data collection, both written and field data, data related to the object of research. The written data collection was carried out on a number of sources, both primary and secondary, in the form of archives, articles, and books.

The data obtained through field surveys in Kampung Naga, in the form of mythology recording and the layout arrangement of Kampung Naga through indigenous approaches. The resources collected were identified and processed through stage description. In the studies of cognitive archaeology, the research is conducted through inductive reasoning that generates an overview of possible parallels between cultural phenomena of the past with today's culture. Artifacts that survived until now are a sign of the reference that comes from the past. The relationship between the sign and the reference creates three characters, i.e. natural, to generate indices; formal, to generate icons; arbitrary, to generate symbols.

The reference may include concepts, values, beliefs, and etc., that thrive and are identified in the middle of the community of the sign maker. Therefore, 
an artifact can be a sign of indices, icons, or symbols, depending on the nature of the relationship between the sign and its reference. The last stage is explanation, in the form of cultural reconstruction of the Kampung Naga community from time to time. As the final part in the analysis of the research about the mythology of Kampung Naga, it in fact should be done patiently to get maximum results as a comprehensive report.

\section{PHILOSOPHICAL FOUNDATION OF FAIRY TALE FOR KAMPUNG NAGA COMMUNITY}

\section{The Myth of the Origin of Kampung Naga}

From the information given by Soeharjo, the Chairman of RT(Neighborhood Association) of Kampung Naga, it was reported that the Sundanese people were once very simple. They used to live on top of large trees on the slopes of Mount Galunggung. Their ancestors who are now buried in the hill, located on west of the village named Sembah Dalem Singaparna. Called Singaparna because he could conquer lions with his power. Singaparna was known as a scholar who possess magic power, the son of King Rajadipuntang, the last King of Galunggung departed to Linggawangi. At that time, the Galunggung Kingdom was attacked by the Kingdom of Sunda under Prabu Surawisesa (1535-1543) because they converted to Islam and no longer acknoledeged the Sunda Kingdom as the Center. Facing the attack, Prabu Rajadipuntang saved the heirloom treasure and pass it on to his youngest son called Singaparana. To carry out the tasks, Singaparana was provided with the power that enabled him able to hide in the crowd. Soeharjo added that the Eyang Singaparna had six sons who inherited all of linuwih power and died in the area where they practiced their knowledge.

The myth of time and space

The myth space is manifested in the belief that the spaces or places have certain boundaries controlled by the spirits, thus they are regarded as being haunted (sanget) and should be given offerings to the sacred place so that it will not disturb them. The boundary here can be found in different categories, such as the river, the front yard of the house next to the road, part of the rice field with the gutter, the place where water comes in which is often referred to as huluwotan, and hillsides. In addition, the Kampung Naga community has a mythical time. The time is called the palintangan, which is the time considered bad so it a taboo to carry out a ritual, or to do other important activities such as farming, and travelling. The taboo is based on the calculation of dawuh. 


\section{ANALYSIS OF THE VALUE OF FAIRYTALE IN KAMPUNG NAGA}

The settlement pattern at Kampung Naga formed as groups. Houses are built in close to each other on a hillside in an area of land which is not of the same height. The hillside houses are made up of four levels. The residential houses are generally located on the North and South of the village. In the middle of the village is the mosque and the bale (hall) located side by side. To the East of the mosque is a square called alun-alun. Parallel to the mosques on the West, there is a higher ground regarded for a holy building called bumi ageung. Water sources in the form of a spring is available in the southern part of the village from which the residents of Kampung Naga get clean water sufficient to fulfill the needs for cooking meal and for drink. The rice fields are situated on the West and East of the settlement. Another important building is the sung lisung, i.e. the building used by the community as a place for pounding rice. The other part of Kampung Naga is a sacred forest called Hutan Keramat which lies to the East of the village. This sacred forest is surrounded by the Ciwulan River which is a line of demarcation for the overall acreage of the sacred forests. The sacred Tomb, which is a grave of Sembah Dalem Singaparna (ancestor of Kampung Naga) is located to the West of Kampung Naga.

The belief in the unseen beings by the community of Kampung Naga to is still held strongly. Jurig cai is one of the unseen beings that inhabits water or the river especially the deep part (called "leuwi"). Then "ririwa" i.e. the one that scares humans at night. There is also another unseen being called "kunti anak" that originates from pregnant women who died and she likes to bother pregnant women or those who are having a baby. These places are referred to as sanget (scary). There are other places made sacred to the people of Kampung Naga such as the grave Sembah Eyang Singaparna, Bumiageung and the mosque are considered sacred. Taboos, dietary restrictions or pamali for the community Kampung Naga are still dutifully carried out especially with regard to the everyday life activities. The restrictions or pamali are unwritten law provisions which are obeyed by everyone related to many aspects of life for example how to build a home and its layout, the direction where the home should face, clothes, arts, ceremonies and so on. The shape of the home at Kampung Naga is usually in the form of a stage home constructed of bamboo and wooden materials. The roof should be of a palm leaf, or reeds; the floor must be made of bamboo or wooden boards. The house should face North or South with the sides facing West or East. The wall is made of bamboo woven with sasag pattern. The house should not be painted and surrounded by a wall, although the owner can afford to build one. The house also should not be equipped with furniture, such as chairs, tables and beds. 
The house should not have doors in two opposite directions. This is because according to a superstition commonly believed in Kampung Naga that rizki (money, income, etc) belonging to the house coming from the front door will go out through the back door. In addition they also avoid to install the door aligned in a straight line. In the field of the arts, the community at Kampung Naga has restrictions or taboos for the kinds of performing arts from outside the village such as wayang golek, dangdut, pencak silat, and the art of others who use goong music. Meanwhile, the art performance allowed should be one belonging to the community's ancestral heritage such as terbangan, angklung, beluk, and rengkong. The beluk art is now rarely performed, whereas the rengkong is unknown anymore especially to the younger generation. For those who want to watch pencak silat, and so on, they are allowed to do so but the arts should be performed outside the territory of Kampung Naga. There are many other restrictions or taboos especialy on Tuesdays, Wednesdays, and Saturdays.

The Kampung Naga community banned the talk about customs and origins of the village. The community of Kampung Naga greatly respects Sembah Eyang Singaparna who was regarded as their ancestor. Meanwhile, in Tasikmalaya there is a place called Singaparna, but the community of Kampung Naga calls it Galunggung, because the word Singaparna is their ancestral name. Kampung Naga community belief system regarding space is manifested in the the belief that the spaces or places have a certain boundary controlled by certain forces. The boundary here can be found in different categories, such as the river, the front yard of the house next to the road, part of the rice field with the gutter, the place where water comes in which is often referred to as huluwotan, places of the hillsides, a place between the villages and the woods, etc., are inhabited by certain forces. Since places that have certain boundaries are inhabited by certain beings, they are considered sacred or scary (known as sanget in local language). That is why in these places, the community of Kampung Naga likes to give "sasajen" (offerings). Their belief with regard to time is called palintangan. At a certain time, there are particular months regarded as bad timing, so it is a taboo to carry out work like building a house, performing marriage, circumcision, and traditional ceremonies. The time with the said taboos is also called larangan bulan (prohibition of the month). The prohibition of the month falls in the months of Sapar and Ramadan. In the mentioned months, it is prohibited or a taboo to hold ceremony as it coincides with the ceremony of menyepi (remain quiet). Moreover, calculations to determine the "good" days are based on the fateful days in each month.

This research attempts to unravel the myths and counter-myth found in the 
community of Kampung Naga. Myth as part of its values of life, of course, can also be material in the process of the birth of anthropological texts. Anthropological researchers often use myth that as the basis for the creation of their work. However, as the relationship between reality and the assumption of anthropology, the presence of myth in the work of anthropology also has experienced a creative process within anthropological researchers. Myth is presented through new understanding and interpretation. The results of the new understanding and interpretation finally create the counter-myth. Thus, the myth itself always deals with counter-myth on a stretch of historical path of the community.

Furthermore, the results of this research are displayed in a tabular form in accordance with the research problems. The results of the study include (a) the form of reference of the myth, and (b) way of revealing the myth. The results of the study are shown in table as follows.

Table 1 Form of Myth Reference

\begin{tabular}{|c|l|l|}
\hline No & \multicolumn{1}{|c|}{ Reference } & \multicolumn{1}{|c|}{ Variant } \\
\hline 1 & $\begin{array}{l}\text { Interaction between hu- } \\
\text { man beings }\end{array}$ & $\begin{array}{l}\text { Manners } \\
\text { Relationship between a child and the } \\
\text { parents } \\
\text { Relationship between husband and wife } \\
\text { Relationship between men and women }\end{array}$ \\
\hline 2 & $\begin{array}{l}\text { Interaction between hu- } \\
\text { man beings and God }\end{array}$ & $\begin{array}{l}\text { the existence of God. } \\
\text { the nature of human being } \\
\text { the meaning of life and death }\end{array}$ \\
\hline 3 & $\begin{array}{l}\text { Interaction between } \\
\text { human beings and them- } \\
\text { selves }\end{array}$ & $\begin{array}{l}\text { understanding human values } \\
\text { self-esteem and honor }\end{array}$ \\
\hline
\end{tabular}

Based on the table above it appears that the reference of myth and countermyth found in the community of Kampung Naga may be classified into three groups, i.e. (1) interaction human beings, (2) the interaction of humans and God, and (3) human interaction with themselves. The classification is open to facilitate disclosure of myth and counter-myth that in the community of Kampung Naga. The classification is done with the assumption that the myth and counter-myth are always connected with the problem of human beings both as individuals and social creatures. The third classification is considered the principal things inherent in human life.

Table 2. Way of Disclosing the Myth 


\begin{tabular}{|l|l|l|}
\hline No & Disclosure style & Focus \\
\hline 1 & Parody & $\begin{array}{l}\text { Religious figures } \\
\text { Human behavior } \\
\text { Origin of humans } \\
\text { Puppet characters }\end{array}$ \\
\hline 2 & Satire & $\begin{array}{l}\text { Virginity problem } \\
\text { Religious awareness }\end{array}$ \\
\hline 3 & Dialectic & $\begin{array}{l}\text { Manners } \\
\text { Meaning of love }\end{array}$ \\
\hline
\end{tabular}

From the table above it can be seen that the disclosure myths and countermyths in the the community of Kampung Naga is done through three ways, namely (1) parody, (2) satire, and (3) dialectic. The way shows the result of the interpretation of an anthropological researcher on the phenomenon of myths and counter-myths existing in the society which further appears in the work of anthropology.

Traditional Ceremony:

\section{Ceremony of Menyepi}

The ceremony is observed on Tuesdays, Wednesdays, and Saturdays. This ceremony according to the people of Kampung Naga is very important and has to be performed as it is also an attempt to avoid any talk about the adat (customs).

\section{Ceremony of Hajat Sasih}

The intent and purpose of this ceremony is to ask for the blessing and salvation to the ancestors of Kampung Naga, and express gratitude to God Almighty.

\section{Wedding Ceremony}

The wedding ceremony for the people of Kampung Naga is a ceremony that is conducted after the completion of the covenant of marriage. As for the stages of the ceremony are as follows: ceremony of sawer, nincak endog, opening doors, ngariung, ngampar, and completed with munjungan.

\section{Shape of the Building}

The houses in Kampung Naga are have the same shape and the layout is fixed. The shape is a rectangular stage house, with a height of approximately $50-60$ $\mathrm{cm}$. the roof has a shape of suhunan julang ngapak, i.e. the length of both sides extended or added, so it looks like stretched bird wings. The additional length of the roof is called leang leang. With such a uniform roof, it appears to be a triangular shape when viewed from the front and the back. At the point where both ends of the roof meet is a point that forms the top corner of the front and the rear part, usually mounted with rings made of bamboo to form a half 
circle or straight or curved resembling horns. The parts that looks like a horn is called " cagak gunting or capit hurang".

Generally the roofing materials are made of coconut leaves, tepus leaves and Arenga palm leaves. The ceilings are made of woven bamboo. Pillars of wood are used to support the roof frame. For the foundation pole (tatapakan) uses natural rock cut in the shape of a rectangle. The walls of the houses in Kampung Naga are made of woven bamboo with two kinds of weaving patterns of kepang and sasag. The door is made of wood and shaped a rectangle measuring 1.75 x 0.75 meters. Windows are rectangular shaped and wooden framed with a certain vertical distance called jalosi, as well as wooden shutters as a covering. Glass is also used as a cover. The floor is made of wooden board, which used to be made of bamboo slab (papuluh). The golodog is also made of wooden board or bamboo, but sometimes rock is used in place of the golodog. The front area of the house is used to receive guests. The kitchen is used for cooking. This room has a function as a family bedroom at night, and used as a place to receive guests in the selamatan or family ceremony.

\section{IMPLEMENTATION OF MYTHS IN DAILY LIFE}

There are some important aspects in the relation between fairy tales the the daily ritual of the community of Kampung Naga implemented in the form of ceremonial rituals. Some forms of traditional rituals can be described in the next section that indicates the function of thre relation between fairy tales and the communit.

\section{HAJAT SASIH CEREMONY}

The ceremony of Hajat Sasih is carried out six times a year, or once in six months, it is celebrated in Islam. This is a ceremony aimed to respect the deceased ancestors which is carried out in a single day without halting the course of the ceremony, even when it rains, as rain is considered a gift. Each month the implementation is held on the three dates to keep the possibility of a predetermined date coincides with other ceremonies, especially the nyepi ceremony. The ceremony starts at 9am and ends at $4 \mathrm{pm}$, led by the kuncen the lebe and the elders of the village. It begins with the reading of a prayer together, followed by the bebersih and the sacred pilgrimage to the tombs as the core of the ceremony which is performed by men only. The entire ceremony participants wear woven white robes, sarong, batik headband (totopong), and a belt (beubeulit) made of white fabric, too. This ceremony outfit is not to be worn with jewelry or footwear. 


\section{NYEPI CEREMONY}

The nyepi ceremony is conducted on every Tuesday, Wednesday, and Saturday. The respect of the community of Kampung Naga for this ceremony is very high and can shift the performance of other ceremonies. The designation of the nyepi ceremony does not reflect an atmosphere of silence and halt of all daily activities and observed by all members of society, children, young and old. If seen from the core activity, in fact, this ceremony may be more appropriately called abstinence, particularly in terms of actually avoiding the discussion of customs as well as the origin of the community of Kampung Naga, both among fellow community members as well as with other foreign guests or visitors.

\section{HARVEST CEREMONY}

The harvest ceremony is a ceremony of individuals, meaning if a family would harvest the results of their rice field, then the family hold the ritual of harvest in order to set a day when harvesting can be carried out. Searching for the harvest day is done at the family home that will harvest the crops, under the direction of candoli, or more often by the kuncen of Kampung Naga assisted by the lebe and elders of the village. This ceremony is etermined through a series of calculations that are called palintangan. After the family get the good day, then the rice harvest is held, and then closed with a ceremony of Thanksgiving to Nyi Pohaci Sang Hyang Asri. On the harvest day, the families who will be harvesting must prepare the requirements among others, sawen, tanjeur, pucuk gantung, (pupuhunan), empos, tumpeng rice, and other complementary offerings. These requirements are used in a procession of taking the 'mother' of rice.

\section{GUSARAN CEREMONY}

Gusaran or circumcision ceremony at Kampung Naga society is done en masse, meaning that each boy would be circumcised at the same time, i.e., in the month of Rayagung. The procession of the ceremony consists of three core activities, i.e., gusaran, lekasan, and wawarian. However, if observed carefully, there are actually a number of ceremonies that are performed together into a precursor of gusaran ceremony itself. A series of ceremonies (lekasan) fused into the gusaran ceremony in its entirety and no less important and interesting to observe is getting a partner, doing bebersih, giving advice, parading around the village, ngala beas, hair cutting, scrambling for sawer, circumcision and wawarian. 


\section{WEDDING CEREMONY}

In general the marriage tradition of the Kampung Naga community is similar to that of the Sundanese custom. However, in practice it still comes with the marriage tradition of Kampung Naga. Before the covenant of marriage, the prospective couple must first fulfill some requirements of the administration. The covenant of marriage is done through ijab kabul (offer and acceptance) called dirapalan. Because the people of Kampung Naga are Muslims, marriage is performed done in front of a penghulu (a person tasked to marry people) and recorded in the Office of Religious Affairs (KUA) by an officer of the local registrar of marriages. Wedding ceremony at Kampung Naga is simple. In addition to the economic consideration, the venue is also limited so that the invitations just revolve around the family of the newlyweds. Before conducting the wedding ceremony, the preparation that should not be missed, according to the custom, is to determine a good day, hold seserahan ceremony, perform ngeuyeuk seureuh and then wedding ceremony shall continue.

\section{IMPLEMENTATION OF THE FAIRY TALE FOR THE COMMUNITY KAMPUNG NAGA}

In general, cultural heritage is the actual remnants that could not be separated from the preservation of the culture, so that the process of preservation is also something of a legacy. More specifically, cultural heritage is the inheritance of Indonesia which includes natural and cultural heritage that form a rich inheritance, which is a natural gift, taste, and works of over 500 ethnic groups in Indonesia, either individually, a fusion with other cultures, and as the unity of the people of Indonesia in the history of its existence. The Archaeological Resources or objects of cultural heritage, according to Law No. 5/1992, are as follows: first, a manmade object, moving or not moving in the form of entity or group, or its parts or fragments, which are at least 50 years old, or represent at least 50 times a year, and is considered to have value important to history, science, and culture. Second, natural objectsconsidered as important items as mentioned in Law No. 5/1992, archaeological resources also have important ethnic and public values.

Kampung Naga as one of Archaeological Resources have important cultural ethnic, and public values,. Thus, to take advantage of the resources, Kampung Naga culture has to be examined through research so they can understand the benefits so that it then can be translated into knowledge for the society, so that this process originates from the society members and to them it should be returned. 


\section{FAIRY TALE AND ITS IMPACT ON THE PATTERN OF COMMUNI- TY OF LIFE}

As we know, the work of anthropology can be considered one of the types of social institution. In that view, anthropology is considered capable of manifesting the life which in the broad sense is a social reality (Wellek, 1976: 94). In other words, anthropology is a social document.

Utilization of myth as a source of research in anthropology can be returned to the above conditions. In the sense that the disclosure and the use of the myth in the work of anthropology are not solely aimed at delivering information based on factual record but may contain specific objectives as well. Utilization of the myth is among others to see the condition of the community so that the works of anthropology create a reflection of the existence of the community. Thus, myths are not simply be complementary but can serve as a means of reconstructing the condition of the society. It can be attributed to the fact that humans have always been surrounded by myths and the myth itself is always in two reciprocal, myth and counter-myth.

Mircea Eliade maintained that religious people have a certain attitude toward life, the world, human beings, and what they regard as sacred. The world to them is limited to areas that are already known, as the cosmos, a region that is already "concentrated". Meanwhile the region outside is a chaotic world as the place of the spirits, the Jinn, the demons, and the like. The area could return to normal through re-creation of cosmogony (universe) by the gods or supernatural powers through the ceremony. In principle, the universe consists of three layers, namely: the upper world is a divine world, heaven, the place of the gods, and its ancestors; the middle world is a world inhabited by living things such as humans, animals, and plants; and the underworld is a place where living creatures die. The third layer is connected by an axis called axis mundi. The axis mundi is located at the center of the world that connects one layer with another. Through the axis mundi, man can relate to the upper world and the underworld.

In a mythological story called Kropak 422, a story depicting the cosmology of the Sundanese in the 14-15 century AD, it was said that the universe is divided into three worlds, namely the sakala (real world), niskala (unseen worlds), and jatiniskala (real unseen world). Residents of the sakala are a variety of creatures that can be seen and touched, such as humans, animals, plants, and so on. Niskala is the place for immortal creatures, in the form of unseen beings such as gods, angels, neutral spirits, called syanu, bayu, sabda, dan hedap. Some of them have been known by the names and their respective task in the supernatural world, in heaven and in hell. They are a lot in numbers and can join between each other. If the neutral spirit merged with bayu, sabda, 
and hedap, the combination is called syaku sukma. The sukma that is casted to sakala, will join the unwanted physical evils so that among them some will transformed into humans, animals, or plants. Meanwhile humans who are too carried away with lust will become a greedy giant. Their sukma can only return to the niskala world as a dweller of hell. Though according to the rules of the gods, they could have gotten waivers, however they must experience some soul reincarnation into the realms of sakala where the great King becomes the guard of the world.

Inhabitants of jatiniskala are The Single Being called the Sang Hyang Manon. The Supreme Creator is referred to as the Ijunajati Nistemen, creator of the limit but it is not exposed to the limit. A similar view is also obtained from the Serat Catur Bumi and Sang Hyang Raga Dewata, Sewaka Darma, Kawih Paningkes dan Jatiniskala, as well as Sri Ajuna. In spatial arrangement, Kampung Naga is divided into three regions, namely, the sacred area, clean area and dirty area. The sacred area is a small hill called the Bukit Naga, the sacred forest (leuweung karamat) in the west side of the Village, and the protected forest (leuweung larangan) to the east of Ciwulan.

In the hills and forests of the leuweung karamat (sacred forests) are where the graves lie, including the tomb of the ancestors. This area can only be visited by men during the ceremony at hajat sasih. Therefore, the protected forest is home to the spirits (dedemit) who were casted away by the Sembah Dalem Singaparana. The first house built here became the residence of Singaparna and now this place is called bumi ageung. This area is strictly prohibited to be touched by anyone, either tourists or residents of Kampung Naga.

The clean area is the area inside the fence where the community of Kampung Naga settlements are built on. This area is free from objects that may be littering the village. In this area people build homes, including one belonging to the kuncen, head of RT (neighborhood association) and the location for bumi ageung, mosque, leuit, while patemon is the dirty area that does not need to be cleaned at any time. This region is a region with ground lower than the settlement, located adjacent to the Ciwulan. In this area, among others, there are showers and a sanitary facility, cattle enclosure, saung lisung, a pond. In the cosmological community, the three areas are the representations of the Cosmos of Kampung Naga.

Negotiation between the local belief (i.e. Prehistoric megalithic tradition in terms of veneration to the deceased Ancestors, in Hinduism and Buddhism), and the teachings of Islam can be seen in the spatial arrangement of Kampung Naga. The arrangement is based on wind direction and the holy Mountain(Gunung Mahameru) which is described as follows: on the 
west side is the leuweung karamat which is where their family and their ancestors were buried; the village where they live and farm is located in the middle, and the place for the dedemit is to the east. The way they built the structure is based on the upper -middle-below, or good-neutral-bad. The lueweung larangan is on the east and the leweung karamat on west are a source of sacred power in their everyday lives.

The lueweung larangan is a chaotic place for evil spirits (dedemit), and the leweung karamat is a source of goodness. The mosque and the heirloom become a liaison to direct the sacredness towards the West. Negotiations between Islamic teachings and the local teachings can be seen in the placement of the sacred forest and bumi ageung which is located on the west of the mosque. When Islam spread into the area, the community at Kampung Naga believed that the Qiblah is the symbol of the Kaaba, thus facing the Qibla means first one must go through the sacred forest and bumi ageung. The desire to get the sacredness of the Kaaba is preceded by linking oneself to the ancestors buried in the sacred forest (Leuweung keramat).

This view may be the basis of their rejection of those who have performed the Hajj.Performing the Hajj pilgrimage means visiting to the grave of the Prophet directly, which is considered sacred. Therefore, they do not need the Qibla to be wrapped by the Earth and the sacred Leuweung Ageung. Thus, the axis mundi of composition that can be seen in the entire house is centered on bumi Ageung and bumi Ageung is connected or centered on the sacred forest, the place of the ancestors. Such condition requires humans to thoroughly and carefully live a life in the world, because both worlds have influenced the time of human life, that the good time and the bad. In all activities, both in the search for safety, prosperity, and the avoidance of catastrophe, they are based on three words, namely, Bismillah, associated with the beginning and origin (upper world); Alhamdulillah, related to the life expectancy of a good man (middle world); and Astaghfirullah, which connects with the world that is not good. Cosmological pattern can also be seen in the form of the homes in Kampung Naga. The home (imah) or euphemized as the earth is part of a series of cosmogony as the actual content of the meaning of the Earth. Therefore, imah or the earth for the people of Kampung Naga is a building that already has rules in the construction that should be aligned with the principles of returning to nature. The divisions of the upper, middle, and the under world can be found in the spatial arrangement as indicated in the previous chapter.

\section{CONCLUSION}

The myth a medium for the ancient society to find the truth in life. The myth 
of a religious ceremony performed by placing the human being in the sacred time and place. The philosophical foundation of the community of Kampung Naga mythology which becomes the patterns of thought and way of life is transformed into an integral part of daily life patterns adopted by the society at KampungNaga. This can be analyzed in the ritual ceremonies, such as Menyepi,Hajat Sasih as well as a wedding ceremony.

The houses in Kampung Naga are have the same shape and the layout is fixed. The shape is a rectangular stage house, with a height of approximately $50-60$ $\mathrm{cm}$. The roof has a unique shape where the length of both sides extended or added, so it looks like stretched bird wings. The additional length of the roof is called leang leang. With such a uniform roof, it appears to be a triangular shape when viewed from the front and the back. At the point where both ends of the roof meet is a point that forms the top corner of the front and the rear part, usually mounted with rings made of bamboo to form a half circle or straight or curved resembling horns. The parts that looks like a horn is called "cagak gunting or capit hurang".

The implementation of the mythology in the pattern of community in Kampung Naga village is manifested in simple life, helping each other. Houses are built in close to each other on a hillside in an area of land which is not of the same height. The hillside houses are made up of four levels. The residential houses are generally located on the North and South of the village. In the middle of the village is the mosque and the bale (hall) located side by side. To the East of the mosque is a square called alun-alun. Parallel to the mosques on the West, there is a higher ground regarded for a holy building called bumi ageung. Water sources in the form of a spring is available in the southern part of the village from which the residents of Kampung Naga get clean water sufficient to fulfill the needs for cooking meal and for drink. The rice fields are situated on the West and East of the settlement. Another important building is the sung lisung, i.e. the building used by the community as a place for pounding rice. The other part of Kampung Naga is a sacred forest called Hutan Keramat which lies to the East of the village. This sacred forest is surrounded by the Ciwulan River which is a line of demarcation for the overall acreage of the sacred forests. The sacred Tomb, which is a grave of Sembah Dalem Singaparna (ancestor of Kampung Naga) is located to the West of Kampung Naga.

The ceremony of menyepi is observed on Tuesdays, Wednesdays, and Saturdays. This ceremony, according to the people of Kampung Naga, is very important and has to be performed as it is also an attempt to avoid any talk about the adat (customs). The intent and purpose of the Hajat Sasih ceremony is to ask 
for the blessing and salvation to the ancestors of Kampung Naga, and express gratitude to God Almighty. The wedding ceremony for the people of Kampung Naga is a ceremony that is conducted after the completion of the covenant of marriage. As for the stages of the ceremony are as follows: ceremony of sawer, nincak endog, opening doors, ngariung, ngampar, and completed with munjungan.

Generally the roof materials of the houses in Kampung Naga are made of coconut leaves, tepus leaves and Arenga palm leaves. The ceilings are made of woven bamboo. Pillars of wood are used to support the roof frame. For the foundation pole (tatapakan) uses natural rock cut in the shape of a rectangle. The walls of the houses in Kampung Naga are made of woven bamboo with two kinds of weaving patterns of kepang and sasag. The door is made of wood and shaped a rectangle measuring 1.75 x 0.75 meters. Windows are rectangular shaped and wooden framed with a certain vertical distance called jalosi, as well as wooden shutters as a covering. Glass is also used as a cover. The floor is made of wooden board, which used to be made of bamboo slab (papuluh). The golodog is also made of wooden board or bamboo, but sometimes rock is used in place of the golodog. The front area of the house is used to receive guests. The kitchen is used for cooking. This room has a function as a family bedroom at night, and used as a place to receive guests in the selamatan or family ceremony.

\section{REFERENCES}

Ahimsa-Putra, Heddy Sri. 1994. "Strukturalisme Levi-Strauss: Sebuah Tanggapan” dalam Basis April, Hal. 122-135.

1995, “Claude Levi-Strauss: Butir-Butir Pemikiran

Peneliti

Budaya" Kata pengantar dalam Octavio Pas Levi-Strauss Empu Peneliti budaya Struktural. Yogyakarta: LKIS.

1997. "Levi-Strauss, Orang-Orang PKI, dan Nalar

Jawa": Telaah Peneliti budaya Struktural Dongeng Etnografis dari Umar Kayam.

Yogyakarta: Makalah Seminar Seni, Budaya dan Ilmu Pengetahuan" UGM, 11-12 Juli. 1999. Struktur Simbolisme Budaya Jawa Kuno: Yang Meneng' dan Yang 'Malih'. Yogyakarta: Makalah diskusi di Javanologi dan Jarahnitra Yogyckarta.

Ayatrohaedi, dkk. 1987. Kawih Paningkes dan Jatiniskala: Alih Aksara dan Terjemahan. Bandung: Sundanologi. 
Badcock, CR. 1975. Levi-Strauss; Structur alism and Sociological Theory. London Hutchinson \& Co Ltd.

Bertens, K. 1996. "Strukturalisme”, Bab 10 dalam Filsafat Barat Abad XX Jilid ll. Jakarta: Gramedia.

Binford, Lewis R. 1972. An Archaeological Perspective. New York: Seminar Press.

Danasasmita, Saleh, dkk. 1987. Sewaka Darma, Sanghyang Siksakandang Karesia,

Amanat Galunggung: Transkripsi dan Terjemahan. Bandung: Sundanologi.

Dark, K.R. 1995. Theoretical Archaeology. Ithaca, New York: Cornell University

Press, hlm. 143.

Darsa, Undang A. Dan Edi S. Ekadjati. 2006. Gambaran Kosmologi Sunda. Bandung: PT Kiblat Buku Utama.

Cremers, Agus dan John de Santo. 1995. Mitos Dukun dan Sihir. Yogyakarta: Kanisius.

Cremers, Agus. 1997. Antara Alam dan Mitos. Flores: Nusa Indah.

Dhavamony, Mariasusai. 1995. Fenomenologi Agama, edisi ke 10. Yogyakarta: Kanisius

Dirjosuwondo. 1984. Mitos Rafu Adil Jawa sebagai Usaha Motivasi Kembali Penyatuan Jenggala dan Kediri. Jakarta: Analisis Kebudayaan, Th. IV No 1, Depdikbud.

Ekadjati, Edi S., dkk.. 2000. Serat Catur Bumi dan Sang Hyang Raga Dewata. Edisi

dan Terjemahan Teks serta Deskripsi Naskah. Bandung: The Toyota Foundation dan Fakultas Sastra Uiversitas Padjadjaran.

Ember, Carol R. dan Marvin Ember. 1986. “Teori dan Metode Antropologi Budaya"

Dalam T.0 Ihromi (Ed.) Pokok-Pokok Antropologi Budaya. Jakarta: Yayasan Obor

Indonesia.

Eliade, Mircea.The Sacred and the Profan. 1959. New York: Harcourt, Brace \& World Inc.

Geldern, Robert Heine. 1982. Konsepsi Tentang Negara \& Kedudukan Raja di Asia Tenggara. Jakarta: CV Rajawali.

Jong, De Josselin, P.E. 1977. Structural Anthrophology in the Netherlands. Belanda: The HagueMartin us-Nijhoff.

Kamajaya, Partokusumo, Karkono. 1995. Kebudaya an Jawa, Perpa duannya dengan Islam, Yogyakarta:IKAPI Cabang Yogyakarta.

Kerk. 1983. Myth; Its Meaning and Functions in Ancient and Other Culture, 
London: University of Californea.

Kluckhohn, Clyde. 1942. "Myths and Ritual: A General Theory", dalam Harvard Theological Review, XXXV, hlm.78-79.

Leach, Edmund. 1968. Claude Levi-Strauss. New York: Penguin Books.

Levi-Strauss, Claude. 1974 . Anthrophology Structural Volume II, Diterjemahkan oleh M. Kyton. New York: Pinguins Books.

Lane, Michael (Ed.) 1970. Introduction to Structuralism. New York: Basic Books, Inc

Maria, Siti. dkk. 1995. Sistem Keyakinan Pada Masyarakat Kampung Naga Dalam Mengelola Lingkungan Hidup (Studi Tentang Pantangan dan Larangan). Jakarta: Proyek Pengkajian dan Pembinaan Nilai-nilai Tradisional Direktorat

Jenderal Kebudayaan.

Masinambau, E.K.M. 2001. "Teori Kebudayaan dan Ilmu Pengetahuan", dalam Meretas Ranah: Bahasa, Semiotika, dan Budaya, Ida Sundari Husen dan Rahayu Hidayat. Yogyakarta: Bentang Budaya.

Munandar, Agus Aris. 2004."Memaknai Warisan Masa Lalu: Data Arkeologi dan Karya Sastra", dalam Sang Tohaan. Persembahan untuk Prof.Dr. Ayatrohaedi, Bogor: Akademia.

Noorduyn, J., dan A. Teeuw. 2006. Three Old Sundanese Poems. Leiden: KITLV Press.

Peursen, C. A. van.. 1988. Strategi Kebudayaan. Yogyakarta: Kanisius

Purwitasari, Tiwi. 2006. "Pemukiman dan Religi Masyarakat Megalitik: Studi Kasus Masyarakat Kampung Naga, Jawa Barat", dalam Arkeologi dari Lapangan ke Permasalahan. Jakarta: IAAI, hlm.175-185.

Rif'ati, Heni Fajria dan Toto Sucipto. 2002. Kampung Adat dan Rumah Adat di Jawa Barat. Bandung: Dinas Kebudayaan dan Pariwisata Propinsi Jawa Barat.

Publisher dalam Robert A Georges (Ed.) Studies on Mithology. Nobleto Onterio: The Darsey Press.

Paz, Octavia. 1995. Levi-Strauss Empu Antr opologi Struktural. Terjemahan Landung Simatupang. Yogyakarta: LKIS.

Pettit, Philip. 1977. The Concep t of Structuralism: A Critical Analysis. Berkeley \& Los Angeles: University of .Californea Press.

Pigeaud, Theodore, G. Th. 1977. 1977 . Structural Anthropology . Nederland: The Hague, Marnitus Nyhoff.

Rossi, Inc. 1974. "Structuralism as Scientific Method" dalam Rossi (Ed.) The Unconscious in Cultural; The Structuralism of Claude Levi-Strauss in Perspective. New Yorks E.P. Dutton \& Co, Inc.

Sastroatmodjo, RPA. 1997. "Konsep Managerial Kekuasaan Jawa; dalam Di- 
mensi dan Kontemplasi”. Yogyakarta; Makalah Di skusi Alternatif, Fakultas Sospol Atmajaya.

Sri Sultan HB X. 1994. "Peran Media Massa dalam Proses Transformasi Budaya”. Yogyakarka: Makalah Temu Redaktur Budaya II, 8 Juni.

Suganda, Her. 2006. Kampung Naga: Memepertahankan Tradisi. Bandung: PT Kiblat Buku Utama

Suhandi Shm., A. 1982. Penelitian Masyarakat Kampung Naga di Tasikmalaya. Bandung: Universitas Padjadjaran.

Sumardjo, Jacob. 2003. Simbol-Simbol Artefak Budaya Sunda: Tafsir-Tafsir Pantun Sunda. Bandung: Kelir.

2006. Khazanah Pantun Sunda: Sebuah Interpretasi. Bandung: Kelir.

Susanto, P.S. Hary. 1987. Mitos, Menurut Pemikiran Mircea Eliade.Yogyakarta: Kanisius.

Widayati, Naniek. 2003. "Strategi Pengembangan Warisan Budaya: Sebuah Pandangan dari Sisi Arsitektur", dalam Kongres Kebudayaan Indonesia ke V, Bukittinggi, 19-23 Oktober. Wagner, Louis, A. 1987. "Pengantar Buku" Morfologi Cerita Rakyat karya V Rropp."

Terjemahan Noriah Taslim. Kualal umpur: Dewan Bahasa dan Pustaka Kementerian Malaysia.

\section{Internet}

Ahmad Gibson AlBustomi, "Islam-Sunda Bersahaja di Kampung Naga". Posted on April 14th, 2006, http://g13b.blogdetik.com, diakses 21 Oktober 2012.

Ahmad Gibson Al-Bustomi, "Struktur Kosmologis dan Apresiasi Seni Tradisi", Posted on April 18th, 2006, dalam http://g13b.blogdetik.com, diakses 21 Oktober 2012.

Ahmad Gibson Al-Bustomi, "Latar kosmologi Seni Tradisi: Kritik Nalar Poskolonial”, July 11, 2008 dalam http://averroes.or.id/2008. diakses 21 Oktober 2012. http://gerbang.jabar.go.id/kabtasikmalaya http://g13b.blogdetik.com, diakses 21 Oktober 2012. 